\section{Commentary: Minimally invasive Ivor Lewis esophagectomy: Unless you have tried it, don't knock it!}

\author{
Matthew R. Egyud, MD, and \\ Shawn S. Groth, MD, MS
}

The evolution of esophageal resection and reconstruction techniques has been "the tale of men repeatedly losing to a stronger adversary yet persisting in an unequal struggle until the nature of the problem became apparent and the war was won." While attempting to reduce the risk of significant morbidity and mortality while maximizing quality of life and long-term survival, the refinement of esophagectomy approaches has also required tenacity on the part of pioneering surgeons to persevere in the face of harsh criticism, such as Dr Alton Oschner's colorful condemnation of Dr Mark Orringer's early transhiatal esophagectomy series presented at the American Association for Thoracic Surgery 58th Annual Meeting, to which Dr Griffith Pearson replied, "Unless you have tried [it], don't knock it! "2,3 Throughout their evolution over the last 30 years, minimally invasive esophagectomy (MIE) techniques have been similarly disparaged. However, there is now level 1 evidence from 2 multicenter randomized trials demonstrating that MIE is associated with less morbidity and improved quality of life as compared with open approaches, without compromising oncologic quality. As experience with minimally invasive techniques expanded to more and more surgeons and with the accumulating body of evidence in the literature supporting its benefits, MIE emerged as the most common esophagectomy approach in the United States ${ }^{4}$ and is the clear direction of the art of esophagectomy. ${ }^{5}$

\footnotetext{
From the Division of Thoracic Surgery, Michael E. DeBakey Department of Surgery, Baylor College of Medicine, Houston, Tex.

Disclosures: Dr Groth is a proctor for Intuitive Surgical, Inc. Dr Egyud reported no conflicts of interest.

The Journal policy requires editors and reviewers to disclose conflicts of interest and to decline handling or reviewing manuscripts for which they may have a conflict of interest. The editors and reviewers of this article have no conflicts of interest.

Received for publication July 29, 2021; revisions received July 29, 2021; accepted for publication July 30, 2021; available ahead of print Aug 8, 2021.

Address for reprints: Shawn S. Groth, MD, MS, Division of Thoracic Surgery, Michael E. DeBakey Department of Surgery, One Baylor Plaza, BCM 390, Houston, TX 77030 (E-mail: Shawn.Groth@bcm.edu).

JTCVS Techniques 2021;10:495-6

2666-2507

Copyright (C) 2021 The Author(s). Published by Elsevier Inc. on behalf of The American Association for Thoracic Surgery. This is an open access article under the CC BY-NC-ND license (http://creativecommons.org/licenses/by-nc-nd/4.0/).

https://doi.org/10.1016/j.xjtc.2021.07.033
}

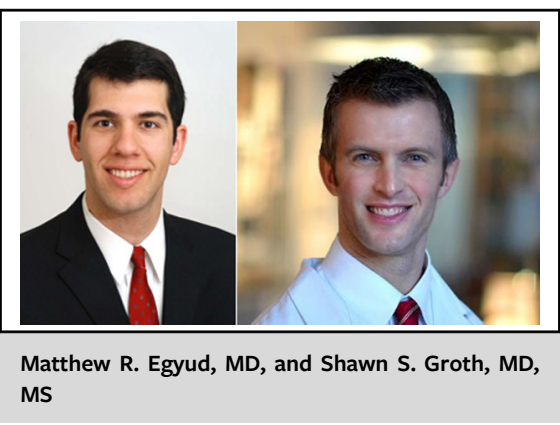

CENTRAL MESSAGE

This video atlas describes a laparoscopic/thoracoscopic minimally invasive Ivor Lewis esophagectomy technique distilled down into 10 steps and backed with excellent published outcomes.

In this issue of JTCVS Techniques, Harrington and Molena ${ }^{6}$ clearly and concisely outline their laparoscopic/thoracoscopic minimally invasive Ivor Lewis esophagectomy technique, distilled down into 10 critical steps. Their video atlas and accompanying text will be a valuable resource for both novices and experienced MIE surgeons wishing to refine their own techniques. ${ }^{5}$ Importantly, for those interested in using this atlas and other resources to begin their own MIE program, a dedicated systematic team approach, persistence, and constant reassessment of one's outcomes are essential, as the authors' and other surgeons from their institution have demonstrated for standard laparoscopic/ thoracoscopic ${ }^{7}$ and robot-assisted MIE. ${ }^{8}$

Compared to the details described in this video atlas, some MIE surgeons (ourselves included) may tout slight differences in the specifics of our preferred MIE techniques, including instrumentation; philosphy on tissue handling and extent of nodal dissection; routine use of a pyloroplasty/pyloromyotomy, a feeding jejunostomy tube, or a formal pedicled omental flap; the specific anastomotic technique; or whether to use a standard laparoscopic/thoracoscopic or robot-assisted approach. However, it should be acknowledged that the true testimony of the quality an operation is an honest appraisal of its outcomes. Indeed, excellent outcomes have been previously published by Dr Mungo and colleagues, further evidence of the quality of the operation detailed in this video atlas. ${ }^{7}$ We spend too little time away from our own busy clinical practices to learn from our 
colleagues and grow as surgeons. This video atlas provides such an opportunity to efficiently learn from an expert esophageal surgeon.

\section{References}

1. Elmslie R. Perspectives in the development of oesophageal surgery. In: Jamieson G, ed. Surgery of the Oesphagus. London: Churchill Livingstone; 1988:3-8.

2. Orringer MB, Sloan H. Esophagectomy without thoracotomy. J Thorac Cardiovasc Surg. 1978;76:643-54.

3. Orringer MB. Commentary. In: Assalia A, Gagner M, Schein M, eds. Controversies in Laparoscopic Surgery. New York: Springer; 2006:181-4.
4. Espinoza-Mercado F, Imai TA, Borgella JD, Sarkissian A, Serna-Gallegos D, Alban RF, et al. Does the approach matter? Comparing survival in robotic, minimally invasive, and open esophagectomies. Ann Thorac Surg. 2019;107:378-85.

5. Groth SS, Burt BM. Minimally invasive esophagectomy: direction of the art. $J$ Thorac Cardiovasc Surg. 2021;162:701-4.

6. Harrington CA, Molena D. Invited video atlas: minimally invasive Ivor Lewis esophagectomy in 10 steps. J Thorac Cardiovasc Surg Tech. 2021;10:489-94.

7. Mungo B, Lidor AO, Stem M, Molena D. Early experience and lessons learned in a new minimally invasive esophagectomy program. Surg Endosc. 2016;30: 1692-8.

8. Sarkaria IS, Rizk NP, Grosser R, Goldman D, Finley DJ, Ghanie A, et al. Attaining proficiency in robotic-assisted minimally invasive esophagectomy while maximizing safety during procedure development. Innovations (Phila). 2016;11: 268-73. 